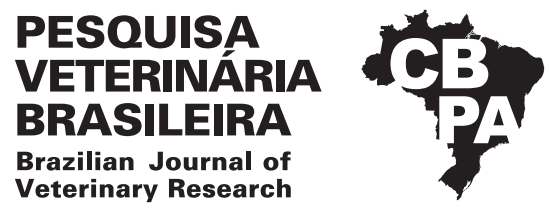

Pesq. Vet. Bras. 39(5):348-354, May 2019 DOI: 10.1590/1678-5150-PVB-5466

Original Article

Animal Morphophysiology

ISSN 0100-736X (Print)

ISSN 1678-5150 (Online)

\title{
Pelvimetry of multiparous Nellore cows in the cycling and early puerperal stages ${ }^{1}$
}

\author{
Regina Lucia S. Silva², Wagner D.C. Oliveira ${ }^{2}$, Daniel Biagiotti ${ }^{3}$ \\ and Guilherme José B.C. Ferreira ${ }^{2 *}$ (D)
}

\begin{abstract}
Silva R.L.S., Oliveira W.D.C., Biagiotti D. \& Ferreira G.J.B.C. 2019. Pelvimetry of multiparous Nellore cows in the cycling and early puerperal stages. Pesquisa Veterinária Brasileira 39(5):348-354. Departamento de Medicina Veterinária, Universidade Federal do Piauí, BR-135 Km 3, Bairro Planalto Horizonte, Bom Jesus, PI 64900-000, Brazil. E-mail: guilherme.ferreira@ufpi.edu.br

Pelvis is an osteoligamentous complex, which is classified as dolichopellic in ruminants. Impairments linked to incompatibility of pelvic canal and fetal size is directly related to pelvic anatomy and disposition. Heritability of pelvic area characteristics varies from moderate to high, demonstrating its importance for animal selection. Pelvimetry can be performed through direct and indirect methods that were accessed in this study aiming to establish a correlation between internal and external pelvic dimensions in multiparous Nellore cows (26 animals) at cycling and early puerperal (up to 30 days postpartum) reproductive stages. Pelvic dimensions measured by descriptive analysis were higher at early puerperal stage. Strong Pearson's correlation was determined between internal and external pelvic dimensions, between reproductive stages, and between pelvic girdle area and internal pelvic area. Significant Tukey's test differences between animals in internal and external dimensions were also found. According to the results, the pelvic anatomy of Nellore cows varies according to their reproductive stage. We detach that and provide data regarding the use of internal pelvic area for animal selection studies on this breed is determined and should be measured using the proposed formula, since it can confirm statistical differences in the areas of pelvic components between animals in the cycling and early puerperal stages.
\end{abstract}

INDEX TERMS: Pelvimetry, pluriparous cows, Nellore cows, cyclic stage, puerperium stage, cattle, pelvis, tocology.

RESUMO.- [Pelvimetria de vacas pluríparas da raça Nellore em estágio cíclico e início do puerpério.] A pelve é considerada um complexo osteoligamentoso, classificada como dolicopélvica em ruminantes. Prejuízos ligados à incompatibilidade canal pélvico/tamanho fetal relacionam-se diretamente à anatomia e disposição pélvica. A característica de área pélvica apresenta herdabilidade variando de moderada a alta, indicando sua importância na seleção animal. A pelvimetria inclui formas direta e indireta. Neste estudo utilizaram-se vinte e seis vacas

\footnotetext{
${ }^{1}$ Received on November 23, 2018.

Accepted for publication on December 3, 2018.

${ }^{2}$ Departamento de Medicina Veterinária, Universidade Federal do Piauí (UFPI), BR-135 Km 3, Bairro Planalto Horizonte, Bom Jesus, PI 64900-000, Brazil. *Corresponding author: guilherme.ferreira@ufpi.edu.br

${ }^{3}$ Universidade Federal do Piauí, Colégio Técnico de Bom Jesus, BR-135 Km 3, Bairro Planalto Horizonte, Bom Jesus, PI 64900-000.
}

multíparas, da raça Nelore, agrupadas de acordo com o estágio reprodutivo, cíclico e em início de estágio puerperal (até 30 dias pós-parto). Através deste, objetivou-se evidenciar a relação das medidas pélvicas internas e externas nos diferentes períodos reprodutivos e coletar obter dados referentes a utilização da área interna do hexágono no estudo pelvimétrico dessa espécie em estágio cíclico ou puerperal. Para tanto, realizou-se, a pelvimetria direta e indireta. Os resultados obtidos, pela análise descritiva, foram maiores para animais em início de estágio puerperal. Por meio da correlação de Pearson podem-se observar fortes correlações entre mensurações pélvicas internas e externas, também entre os grupos propostos, e forte correlação entre elipse pélvica e área interna do hexágono. Pelo teste Tukey diferenças significativas tanto em medidas internas e externas puderam ser demonstradas. Conclui-se que as condições anatômicas da pelve variam de acordo com o estágio reprodutivo do animal, que aferição da área 
pélvica utilizando a formula proposta para área do hexágono interno é relevante pois foi possível comprovar a diferenças estatísticas de áreas nas fases cíclica e puerperal.

TERMOS DE INDEXAÇÃO: Pelvimetria, vacas pluríparas, raça Nellore, estágio cíclico, estágio puerpério, bovinos, pelve, tocologia.

\section{INTRODUCTION}

A commonly problem in bovine breeding is the occurrence of dystocia; it is the main cause of perinatal mortality in calves (Dematawena \& Berger 1997). Racial characteristics, cow and bull conformations, calf size, and crosses with European breeds are the main causes of dystocia in bovines (Schafhauser et al. 2004). Losses due to dystocia occur because of the death of calves, and its effects on subsequent pregnancies and other reproductive events (Bellows et al. 1971).

A narrow pelvis can affect the delivery, making it difficult to expel the fetus (Derivaux \& Ectors 1984). The occurrence of dystocia can be reduced by evaluating mainly the true conjugate diameter (sacropubic diameter), and the median bi-iliac breadth, since the fetus must be smaller than or equal to the female pelvis size for a normal delivery (Oliveira et al. 2003). Incompatibility between pelvic canal and fetal size involves expenses with surgical interventions, medications, longer postpartum recovery period, longer period between deliveries, and the risk of fetal and mother deaths during delivery (Hafez \& Hafez 2000).

Therefore, considering the importance of the Brazilian livestock production, studies on bovine reproduction, especially females, are important to provide information on fetus and cow health to prevent expenses with reproductive problems (Hafez \& Hafez 2000).

Calving occurs, on average, at 292 days in Bos indicus, and at 282 days in Bos Taurus (Paschal et al. 1991). It results from interactions between the mother and the fetus, which is a sequential maturation of communication between endocrine (Knobil \& Neill 1994, Hafez \& Hafez 2000), neural, and mechanical (Hafez \& Hafez 2000) organs. Dilation of the pelvic region occurs during delivery; the release of relaxin - a peptidic hormone that is synthesized in the corpus luteum - is responsible for increasing malleability of the pubic symphysis and sacroiliac joints (Cunningham 1999).

A significant hormonal interference occurs on the constitution of the ligamentous fibers of the pelvic region during the delivery. This change allows a wider dilation of sacrococcygeal and intercoccygeal articulations, and ischiopubic amphiarthrosis, which only becomes completely ossified from a certain age of the animal (Derivaux \& Ectors 1984).

The pelvis is a multiple-function osteoligamentous complex (Oliveira et al. 2003), its denomination derives from the Latin pelvis that means basin. It is classified as dolichopellic in ruminant animals because of the sacropubic diameter in females is larger than the median bi-iliac breadth (Derivaux \& Ectors 1984).

The bony structure of the pelvis consists of the sacrum, first three coccygeal vertebrae, and the coxal bones (left and right) formed by the fusion of ilium, ischium, and pubis (Roberts 1986). The dorsal wall of the pelvis is formed by the sacrum and caudal vertebrae, and the ventral wall is formed by the pubic and ischial bones, including ischial tuberosity (Getty 1986); and its lateral walls are formed by the ilium and the acetabular part of the ischium bones. The articulation between coxal bones (right and left) is an amphiarthrosis called pelvic symphysis (Derivaux \& Ectors 1984).
Visceral palpation via rectal and vaginal can be performed to access the pelvic area to diagnose gestations and dystocia; to explore pelvic and part of abdominal viscera; and to apply reproduction biotechniques for large animals. Thus, pelvic dimensions and delivery are closely related, mostly in cases of fetal-pelvic incompatibility (large fetus compared to mother pelvic area) that commonly results in dystocia (Deutscher 1978, Johnson et al. 1988, Nix et al. 1998). According to Koury Filho et al. (2010) every adopted criteria is the basis for genetic evaluation programs meanwhile morphological characteristics has been proved to present favorable responses to selection. For example, considering a pelvic heritability of 0.36 to 0.67 (moderate to high), and a calf weight at birth of $0.45\left(\mathrm{~h}^{2}=0.3\right.$ to 0.45$)$ (Deutscher 1985), the preferable characteristic for selection is the one of greater heritability (Rice 1994). This can generate calves with higher weights at birth, considering the greater bone structure of the resulting animal; however, gains will depend on the parent been selected for size of the pelvic area to allow their birth.

Pelvimetry has great applicability to the reduction of dystocia index, especially for nulliparous animals, minimizing economic losses (Meijering 1984, Ko \& Ruble 1990, Oliveira et al. 2003) Two measures are fundamental for pelvimetry for pelvic classification: true conjugate diameter (sacropubic diameter), and median bi-iliac breadth. However, other measures can be considered: vertical diameters of the cranial and caudal faces of the pelvis, transversal diameter of the pelvic cavity, transversal diameter of the caudal face of the pelvis, and right and left sacroiliac oblique diameters. Pelvimetry may be direct or indirect. Four types of pelvimeter can be used in the direct method: the manual pelvimeters of Menissier-Vissac (Derivaux \& Ectors 1984) and Rice, and the pneumatic/hydraulic pelvimeters of Krautmann-Litton and Equibov-Litton (Deutscher 1985, Ko \& Ruble 1990). Indirect pelvimetry is the correlation between pelvic and body dimensions (Araújo et al. 2014). The present work aimed to highlight the importance and practicality of direct and indirect pelvimetry by describing the correlation between internal and external pelvic dimensions of multiparous Nellore cows at different reproductive stages (cycling and early puerperal) and provide data regarding the use of measures of internal pelvic area for studies on this breed.

\section{MATERIALS AND METHODS}

This study was carried out at the Experimental Farm of the Federal University of Piauí, in Alvorada do Gurguéia, southern State of Piauí, Brazil. Twenty-six multiparous cows of the Nellore breed were selected for the experiment and divided into two groups. The first group was consisted of 13 cows in the normal reproductive cycling stage and the second group of 13 animals in the early puerperal stage (up to 30 days postpartum).

All animals were adequate physically restrained using a cattle crush for rectal emptying and hygiene of the external anal region and identified to organize the corresponding data before the pelvimetry.

The arms of the Rice pelvimeter were then introduced, closed, and juxtaposed, keeping their internal ends close to the manipulator's hand. The bone formations of interest were located manually and the ends of the device (fixed and movable arm of the pelvimeter) were supported in the bone structures for proper measurement. The internal median bi-iliac breadth (greater internal breadth between the arms of the ilium), dorsal bi-iliac breadth (between the arms of the ilium ventrally to the sacral bone), ventral bi-iliac breadth (between the arms of the ilium at the level of the ilium pubic 
eminences), sacropubic diameter (between the ventral relief of the body of the last sacral vertebrae and the projection located in the pubic symphysis), and internal bi-ischial breadth (greater breadth between ischial tuberosities) were measured (Fig.1A).

Indirect pelvimetry consisted of measuring the external median bi-iliac breadth (between lateral ends of the tuberosities of the right and left coxal bones), external bi-ischial breadth (between lateral ends of the right and left ischial tuberosities), external ilio-ischial breadth (between lateral ends of the right and left coxal and ischial tuberosities), using a tape measure (Fig.1B).

The body dimensions evaluated were animal height (from the ground to the dorsal end of the spinal processes of the first thoracic vertebrae), thoracic width (caudal tangent from the left to the right olecranum end), and thoracic depth (from the caudal wither region to the ventral portion of the sternum), using a hipometer, and body length (from the cranial end of the scapulohumeral joint to the ischial tuberosity), using a tape measure.

The pelvic girdle area (Fig.2A) was obtained by applying Equation 1; and the internal pelvic area (Fig.2B) was obtained using Equation 2.

$$
\begin{gathered}
\mathrm{PGA}=\frac{\mathrm{MBI}}{2} \times \frac{\mathrm{SP}}{2} \times \pi \\
\mathrm{IPA}=\left[\left(\frac{(\mathrm{MBI}+\mathrm{DBI})}{2} \times \frac{\mathrm{SP}}{2}\right)+\left(\frac{(\mathrm{MBI}+\mathrm{DBI})}{2} \times \frac{\mathrm{SP}}{2}\right)\right]
\end{gathered}
$$

Where: $P G A$ is the pelvic girdle área, $M B I$ is the median bi-iliac breadth, $S P$ is the sacropubic diameter, IPA is the internal pelvic área and $D B I$ is the dorsal bi-iliac breadth.

The procedure described was approved (Issue $\mathrm{n}^{\circ}$ 059/09) by the Animal Ethics Committee of the Universidade Federal do Piauí.

The direct and indirect pelvimetry was analyzed by descriptive statistics and Pearson correlation, using the Bioestat 5.3 program. The significance between the dimensions of animals of the different groups (cycling and early puerperal) was evaluated by the Tukey's test, using the SASM program (System for Analysis and Separation of Means).
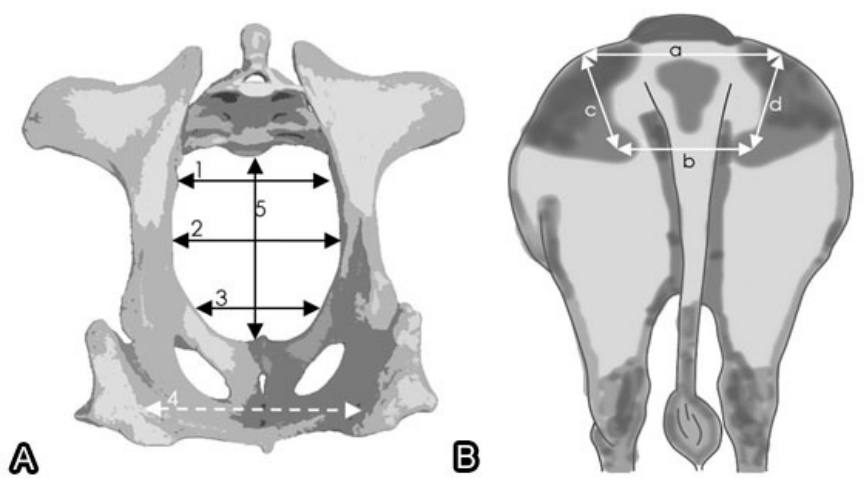

Fig.1. (A) Schematization of the pelvic bones of a bovine, where the arrows show the places used for the internal measurement, respectively: dorsal bi-iliac breadth (1), transverse diameter (2), internal ventral bi-iliac breadth (3), internal bi-ischial breadth (4) and sacropubic diameter (5). (B) Schematization of the hip of a bovine, where the arrows show the places used for the external measurement: External bi-iliac breadth (a), external bi-ischial breadth (b), external ilio-ischial breadth right (c), external ilio-ischial breadth left (d), with the convergence of arrows ac and ad the coxal tuberosity and the convergences bc and bd to the ischial tuberosities. Schemas elaborated by the authors.

\section{RESULTS AND DISCUSSION}

The descriptive analysis of the direct pelvimetry (Table 1 and 2) showed that in the pelvic girdle area presented a higher standard deviation than the other dimensions in both stages (cycling and early puerperal). It was lower than that found for the internal pelvic area, probably due to the number of variables used to obtain these areas - two for the pelvic girdle area, and four to the internal pelvic area. However, the coefficient of variation of the pelvic girdle area was lower than those found for external bi-ischial breadth, and internal pelvic area of multiparous cows in the cycling stage. Animals in the early puerperal stage presented lower coefficient of variation for pelvic girdle area than those in the cycling stage, and higher minimum and maximum areas. The other values of the direct pelvimetry of animals in the early puerperal stage were similar to the maximum values found for those in the cycling stage (Table 1 and 2 ).

The maximum and minimum internal dorsal bi-iliac breadth, internal median bi-iliac breadth, internal ventral bi-iliac breadth, and internal bi-ischial breadth of animals in early puerperal stage was lower than the sacropubic diameter (Table 2). This confirms the results of Oliveira et al. (2003) and classifies the pelvis of these animals as dolichopellic (Derivaux \& Ectors 1984). Rezende et al. (2017) found similar results in Jafarabadi, Murrah, and Mediterranean buffaloes; these animals presented a sacropubic diameter larger than the median bi-iliac breadth, presenting pelvis with similar anatomical form to an ellipse with a vertical main axis. However, according to Tsousis et al. (2010), differences between the height of the pelvic inlet and the diagonal diameter of the pelvic inlet are not significant. These different results may be due to the methods used; pelvimetric dimensions performed in vivo and in carcasses may lead to significant differences. However, even though these differences are significant, they are too small to diversify the obstetric conduction during a possible dystocia (Kolkman et al. 2009). This denotes the consistency of the results obtained in animals when using the Rice pelvimeter.

\section{A}

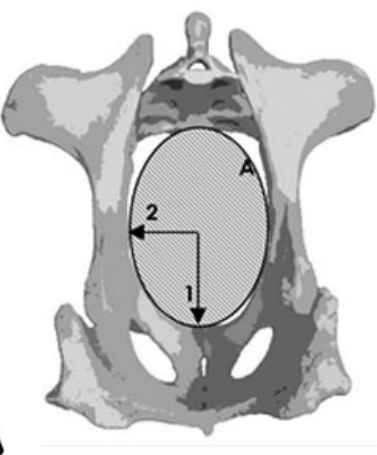

B

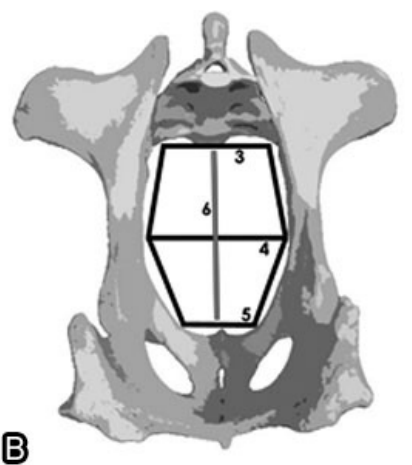

Fig.2 (A) Schematization of the pelvic bones of a bovine. The arrows represent the measurement of the rays of the pelvic ellipse, being: (1) the major radius (vertical diameter/2) and (2) the minor radius (transverse diameter/2) and the region of the pelvic ellipse area, which is obtained from formula $A=1 \times 2 \times \pi$. (B) Schematization of the pelvic bones of a bovine. Internal median bi-iliac breadth (4), sacropubic diameter (6), internal dorsal bi-iliac breadth (3), internal ventral bi-iliac breadth (5). Schemas elaborated by the authors. 
Table 1. Descriptive statistics of direct and indirect pelvimetric measurements of 13 multiparous, cyclic Nellore cows

\begin{tabular}{|c|c|c|c|c|c|c|c|c|}
\hline & $\mathrm{N}$ & Minimum & Maximum & T.A. & A.M. & V.A. & S.D. & C.V. \\
\hline $\mathrm{AH}$ & 13 & 128.00 & 146.00 & 18.00 & 135.27 & 28.03 & 5.29 & $3.91 \%$ \\
\hline $\mathrm{BL}$ & 13 & 140.50 & 161.00 & 20.50 & 151.27 & 39.11 & 6.25 & $4.13 \%$ \\
\hline TW & 13 & 28.00 & 38.50 & 10.50 & 34.88 & 9.51 & 3.08 & $8.84 \%$ \\
\hline EBIS & 13 & 16.00 & 27.00 & 11.00 & 22.04 & 10.81 & 3.29 & $14.92 \%$ \\
\hline EIIR & 13 & 42.50 & 49.00 & 6.50 & 46.27 & 4.48 & 2.12 & $4.58 \%$ \\
\hline IMBIL & 13 & 13.50 & 17.50 & 4.00 & 15.69 & 1.19 & 1.09 & $6.95 \%$ \\
\hline IVBIL & 13 & 12.00 & 16.50 & 4.50 & 14.77 & 1.61 & 1.27 & $8.59 \%$ \\
\hline SP & 13 & 15.00 & 20.00 & 5.00 & 17.65 & 1.68 & 1.30 & $7.35 \%$ \\
\hline PGA & 13 & 159.04 & 274.89 & 115.85 & 218.39 & 845.78 & 29.08 & $13.32 \%$ \\
\hline IBIS & 13 & 11.00 & 17.00 & 6.00 & 14.15 & 2.93 & 1.71 & $12.10 \%$ \\
\hline
\end{tabular}

IDBIL = Internal Dorsal Bi-iliac, IMBIL = internal median bi-iliac, IVBIL = internal ventral bi-iliac, IBIS $=$ internal bi-ischial, $\mathrm{SP}=$ sacropubic, PGA $=$ pelvic girdle area, $\mathrm{AH}=$ animal height, $\mathrm{BL}=$ body length, $\mathrm{TW}=$ thoracic width, $\mathrm{TD}=$ thoracic depth, $\mathrm{EBIL}=$ external bi-iliac, $\mathrm{EBIS}=$ external bi-ischial, EIIR = external ilio-ischial right, EIIL = external ilio-ischial left, IPA = internal pelvic area, $\mathrm{N}=$ number of observations, A.M. = arithmetic means, S.D. = standard deviations, T.A. = total amplitude, V.A. = variance, C.V. = coefficient of variation.

Table 2. Descriptive statistics of direct and indirect pelvimetric measurements of 13 multiparous Nelore cows in puerperal stage

\begin{tabular}{|c|c|c|c|c|c|c|c|c|}
\hline & $\mathrm{N}$ & Minimum & Maximum & A.T. & A.M. & V.A. & S.D. & C.V. \\
\hline $\mathrm{AH}$ & 13 & 131.00 & 152.00 & 21.00 & 138.81 & 36.56 & 6.05 & $4.36 \%$ \\
\hline $\mathrm{BL}$ & 13 & 145.00 & 162.00 & 17.00 & 153.46 & 38.44 & 6.20 & $4.04 \%$ \\
\hline TW & 13 & 32.00 & 42.00 & 10.00 & 37.42 & 9.58 & 3.09 & $8.27 \%$ \\
\hline EBIL & 13 & 43.00 & 53.00 & 10.00 & 49.00 & 8.67 & 2.94 & $6.01 \%$ \\
\hline EBIS & 13 & 21.00 & 28.00 & 7.00 & 24.54 & 5.39 & 2.32 & $9.46 \%$ \\
\hline EIIR & 13 & 42.00 & 53.00 & 11.00 & 46.77 & 6.36 & 2.52 & $5.39 \%$ \\
\hline EIIL & 13 & 43.00 & 54.00 & 11.00 & 47.27 & 7.03 & 2.65 & $5.61 \%$ \\
\hline IDBIL & 13 & 14.00 & 17.00 & 3.00 & 15.50 & 0.75 & 0.87 & $5.59 \%$ \\
\hline IMBIL & 13 & 14.00 & 17.50 & 3.50 & 15.69 & 1.19 & 1.09 & $6.95 \%$ \\
\hline IVBIL & 13 & 13.00 & 16.50 & 3.50 & 15.23 & 1.19 & 1.09 & $7.17 \%$ \\
\hline SP & 13 & 18.00 & 19.50 & 1.50 & 19.08 & 0.20 & 0.45 & $2.36 \%$ \\
\hline PGA & 13 & 208.92 & 260.36 & 51.44 & 235.06 & 270.87 & 16.46 & $7.00 \%$ \\
\hline IBIS & 13 & 12.00 & 16.50 & 4.50 & 14.04 & 1.85 & 1.36 & $9.70 \%$ \\
\hline TD & 13 & 63.00 & 72.00 & 9.00 & 66.46 & 5.64 & 2.38 & $3.57 \%$ \\
\hline IPA & 13 & $3,185.97$ & $4,458.66$ & $1,272.69$ & $3,841.44$ & $167,855.79$ & 409.70 & $10.67 \%$ \\
\hline
\end{tabular}

IDBIL = Internal dorsal bi-iliac, IMBIL = internal median bi-iliac, IVBIL = internal ventral bi-iliac, IBIS = internal bi-ischial, SP = sacropubic, PGA = pelvic girdle area, $\mathrm{AH}=$ animal height, $\mathrm{BL}=$ body length, $\mathrm{TW}=$ thoracic width, $\mathrm{TD}=$ thoracic depth, $\mathrm{EBIL}=$ external bi-iliac, EBIS = external bi-ischial, EIIR = external ilio-ischial right, EIIL = external ilio-ischial left, IPA = internal pelvic area, $\mathrm{N}=$ number of observations, A.M. = arithmetic means, S.D. = standard deviations, A.T. $=$ total amplitude, V.A. = variance, C.V. = coefficient of variation.

The arithmetic means and standard deviations found for both groups (cycling and early puerperal) regarding internal dorsal bi-iliac breadth showed differences; with lower breadths than those found in crossbred female buffaloes (Oliveira et al. 2001), and Girolando cows (Barreto et al. 2004), but higher than that found for Nellore cows (Oliveira et al. 2003) (Table 3). These results were due to conformational differences in the bone structure of crossbred buffaloes, such as their larger body diameter when compared to Nellore cows; and the genetic composition of Girolando animals, since the numerous selections for delivery ability of taurine cows possibly make, indirectly, animals from these crosses to inherit characteristics that favor delivery, such as greater pelvic dimensions. The pelvic girdle area of animals in the early puerperal stage was larger; this may be related to the incomplete reestablishment of bone and ligamentous structures that suffered relaxation during delivery to their original conformation. However, the sacropubic diameter of animals in the cycling stage was higher than those of Nellore cows found by Oliveira et al. (2003) (Table 3). Animals in the early puerperal stage presented larger sacropubic diameter; similar results were found in Guzerá cows by Okuda et al. (1994) (Table 3). The main advantage of knowing these dimensions, measured through pelvimetry, is to avoid fetal-pelvic incompatibility (Araújo et al. 2014), i.e., including in the reproduction system animals with incompatible dimensions. 
According to the Pearson's correlation, the correlations between internal and external pelvimetric dimensions of multiparous cows in the cycling and early puerperal stages were low for most animals, or moderate. The correlation between animal height and sacropubic diameter in animals in the cycling stage was $r=0.34$ (Table 4 ). This is a similar result to that found for crossbred buffaloes (Oliveira et al. 2001) $(\mathrm{r}=0.33)$, and Nellore cattle (Oliveira et al. 2003) $(r=0.20)$. However, this correlation for animals in the early puerperal stage was moderate and negative ( $\mathrm{r}=-0.56$ ) (Table 5), denoting that these dimensions assume a moderate and inverse pattern of development in these animals. The correlation between sacropubic diameter and pelvic girdle area was high $(\mathrm{r}=0.95)$ in animals in the cycling stage (Table 4), and low in animals in the early puerperal stage $(\mathrm{r}=0.18)$ (Table 5). Similar results were found for the correlation between sacropubic diameter and internal pelvic area, which was $r=0.72$ for animals in the cycling stage, and $r=0.12$ for those in the early puerperal stage; and for the correlation between sacropubic diameter and internal dorsal bi-iliac breadth, internal median bi-iliac breadth, and internal ventral bi-iliac breadth, which were high in animals in the cycling stage $(r=0.62, r=0.74, r=0.58$, respectively), and negative and low ( $r=-0.32, r=-0.16, r=-0.34$ respectively) in animals in the early puerperal stage (Table 4 and 5).

These differences were probably due to instabilities of the anatomical position of the bony structures that compose the pelvis during the early puerperal stage, including changes because of the delivery reported by Cunningham (1999) and Derivaux \& Ectors (1984), and incomplete reestablishment of these displaced bones. Thus, these results denote the possible equivalence between using the pelvic girdle area and internal pelvic area in pelvimetric studies.

The animal height and internal dorsal bi-iliac breadth showed correlation of 0.51 in crossbred buffaloes (Oliveira et al. 2001). This is a similar result to those found for the different animal groups in the present work, $r=0.60$ for animals in the cycling and early puerperal stages, showing a significant correlation between these characteristics. The correlation between external and internal pelvic dimensions of Nellore females is low; the correlation between external median bi-iliac and internal median bi-iliac breadths found by Oliveira et al. (2003) was 0.19 , which was a similar result to that found in

Table 3. Data related to arithmetic mean and standard deviation of internal and external pelvimetric measurements observed and reported regularly in the literature by different authors and with different groups of animals

\begin{tabular}{|c|c|c|c|c|c|c|c|c|}
\hline A.M. \pm S.D. & IDBIL $(\mathrm{cm})$ & IMBIL $(\mathrm{cm})$ & IVBIL $(\mathrm{cm})$ & $\mathrm{SP}(\mathrm{cm})$ & $\mathrm{PGA}\left(\mathrm{cm}^{2}\right)$ & $\mathrm{AH}(\mathrm{cm})$ & $\mathrm{BL}(\mathrm{cm})$ & EBIL $(\mathrm{cm})$ \\
\hline $\begin{array}{l}\text { Multiparous and cycling } \\
\text { stage }\end{array}$ & $14.54 \pm 1.38$ & $15.69 \pm 1.08$ & $14.77 \pm 1.27$ & $17.65 \pm 1.29$ & $218.38 \pm 29.07$ & $135.27 \pm 5.28$ & $151.27 \pm 6.24$ & $48.04 \pm 2.82$ \\
\hline $\begin{array}{l}\text { Multiparous and early } \\
\text { puerperal stage }\end{array}$ & $15.5 \pm 0.87$ & $15.68 \pm 1.09$ & $15.23 \pm 1.09$ & $19.08 \pm 0.45$ & $235.06 \pm 16.46$ & $138.81 \pm 6.05$ & $153.45 \pm 6.20$ & $49.00 \pm 2.94$ \\
\hline Okuda et al. (1994)* & $15.14 \pm 0.89$ & & $13.99 \pm 0.83$ & $19.26 \pm 1.33$ & & & & \\
\hline Oliveira et al. (2001)* & $18.5 \pm 1.58$ & & $17.1 \pm 1.57$ & $24.1 \pm 1.78$ & & $137.7 \pm 5.31$ & $143.2 \pm 8.19$ & $63.5 \pm 3.26$ \\
\hline Oliveira et al. (2003)* & $12.69 \pm 1.08$ & $14.32 \pm 1.07$ & $12.2 \pm 0.86$ & $17.68 \pm 1.4$ & $199.42 \pm 26.20$ & $129.75 \pm 4.41$ & $144.21 \pm 7.10$ & $46.19 \pm 2.72$ \\
\hline
\end{tabular}

* Guzerá cows (Okuda et al. 1994), multiparous crossbreed buffaloes (Oliveira et al. 2001), cows of the Nelore breed multiparous (Oliveira et al. 2003), cows of the Girolanda breed multiparous (Barreto et al. 2004); A.M. = Arithmetic means, S.D. = standard deviations, IDBIL = internal dorsal bi-iliac, IMBIL = internal median bi-iliac, IVBIL = internal ventral bi-iliac, $\mathrm{SP}=$ sacropubic, $\mathrm{PGA}=$ pelvic girdle area, $\mathrm{AH}=$ animal height, $\mathrm{BL}=\mathrm{body}$ length, $\mathrm{EBIL}=$ external bi-iliac.

Table 4. Pearson's correlation analysis of the direct and indirect pelvimetric characteristics of cyclic Nellore pluriparous cows

\begin{tabular}{|c|c|c|c|c|c|c|c|c|c|c|c|c|c|c|c|}
\hline & $\mathrm{AH}$ & BL & TW & BILE & EBIS & EIIL & EIIR & BILID & IMBIL & IVBIL & SP & PGA & IPA & IBIS & TD \\
\hline $\mathrm{AH}$ & 1.00 & --- & --- & --- & --- & --- & --- & --- & --- & --- & --- & --- & --- & --- & --- \\
\hline $\mathrm{BL}$ & 0.53 & 1.00 & --- & -- & --- & --- & --- & --- & --- & --- & --- & -- & --- & --- & --- \\
\hline TW & -0.55 & -0.20 & 1.00 & --- & --- & --- & --- & --- & --- & --- & --- & --- & --- & --- & --- \\
\hline EBIL & 0.38 & 0.52 & -0.23 & 1.00 & --- & --- & --- & --- & --- & --- & --- & --- & --- & --- & --- \\
\hline EBIS & 0.33 & -0.11 & -0.25 & -0.18 & 1.00 & --- & --- & --- & --- & --- & --- & --- & --- & --- & --- \\
\hline EIIL & 0.54 & 0.40 & -0.19 & $0.66^{*}$ & -0.35 & 1.00 & --- & --- & --- & --- & --- & --- & --- & --- & --- \\
\hline EIIR & $0.61^{*}$ & 0.43 & 0.07 & 0.46 & 0.04 & $0.75^{* *}$ & 1.00 & --- & --- & --- & --- & --- & --- & --- & --- \\
\hline IDBIL & $0.58^{*}$ & -0.21 & -0.43 & -0.04 & 0.54 & 0.14 & 0.23 & 1.00 & --- & --- & --- & --- & --- & --- & --- \\
\hline IMBIL & 0.06 & -0.37 & -0.23 & 0.10 & 0.27 & 0.02 & -0.01 & $0.66^{*}$ & 1.00 & --- & --- & --- & --- & --- & --- \\
\hline IVBIL & -0.20 & -0.42 & -0.01 & -0.29 & 0.48 & -0.47 & -0.24 & 0.54 & $0.58^{*}$ & 1.00 & --- & --- & --- & --- & --- \\
\hline SP & 0.34 & -0.24 & -0.26 & -0.05 & 0.27 & 0.23 & 0.30 & $0.73^{* *}$ & $0.79^{* *}$ & 0.40 & 1.00 & --- & --- & --- & --- \\
\hline PGA & 0.21 & -0.31 & -0.25 & 0.05 & 0.27 & 0.17 & 0.19 & $0.73^{* *}$ & $0.94^{* * *}$ & 0.50 & $0.95^{* * *}$ & 1.00 & --- & --- & --- \\
\hline IPA & 0.27 & -0.12 & -0.34 & 0.00 & $0.71^{* *}$ & -0.09 & 0.20 & $0.62^{*}$ & $0.74^{* *}$ & $0.58^{*}$ & $0.72^{* *}$ & $0.77^{* *}$ & 1.00 & --- & --- \\
\hline IBIS & 0.50 & 0.46 & $-0.59^{*}$ & -0.15 & 0.19 & 0.04 & -0.10 & 0.07 & -0.43 & -0.29 & -0.13 & -0.31 & -0.14 & 1.00 & --- \\
\hline $\mathrm{TD}$ & 0.15 & -0.34 & -0.20 & 0.02 & 0.32 & 0.09 & 0.16 & $0.73^{* *}$ & $0.94^{* * *}$ & $0.63^{*}$ & $0.92^{* * *}$ & $0.99 * * *$ & $0.80^{* * *}$ & -0.36 & 1.00 \\
\hline
\end{tabular}

IDBIL = internal dorsal bi-iliac, IMBIL = internal median bi-iliac, IVBIL = internal ventral bi-iliac, IBIS = internal bi-ischial, SP = sacropubic, $\mathrm{PGA}=$ pelvic girdle área, $\mathrm{AH}=$ animal height, $\mathrm{BL}=$ body length, $\mathrm{TW}=$ thoracic width, $\mathrm{TD}=$ thoracic depth, EBIL = external bi-iliac, EBIS = external bi-ischial, EIIR = external ilio-ischial right, EIIL = external ilio-ischial left, IPA = internal pelvic area; ${ }^{*} \mathrm{p}<0.05,{ }^{* *} \mathrm{p}<0.01,{ }^{* * *} \mathrm{p}<0.001$. 
Table 5. Pearson's correlation analysis of the direct and indirect pelvimetric characteristics of multiparous cows of the Nelore breed in the puerperal phase

\begin{tabular}{|c|c|c|c|c|c|c|c|c|c|c|c|c|c|c|c|}
\hline & $\mathrm{AH}$ & $\mathrm{BL}$ & TW & EBIL & EBIS & EIIL & EIIR & IDBIL & IMBIL & IVBIL & SP & PGA & IPA & IBIS & $\mathrm{TD}$ \\
\hline $\mathrm{AH}$ & 1.00 & --- & --- & --- & --- & --- & --- & --- & --- & --- & --- & --- & --- & --- & --- \\
\hline BL & 0.09 & 1.00 & --- & --- & --- & --- & --- & --- & --- & --- & --- & --- & --- & --- & -- \\
\hline TW & 0.35 & 0.13 & 1.00 & --- & --- & --- & --- & --- & --- & --- & --- & --- & --- & --- & --- \\
\hline EBIS & $0.63^{*}$ & $0.60^{*}$ & 0.32 & 0.49 & 1.00 & --- & --- & --- & --- & --- & --- & --- & --- & --- & --- \\
\hline EIIL & 0.34 & 0.07 & 0.41 & 0.34 & 0.36 & 1.00 & --- & --- & --- & --- & --- & --- & --- & --- & --- \\
\hline IMBIL & 0.19 & 0.00 & 0.43 & 0.14 & 0.19 & 0.32 & 0.38 & $0.62^{*}$ & 1.00 & --- & --- & --- & --- & --- & --- \\
\hline IVBIL & $0.62 *$ & 0.11 & 0.22 & -0.05 & 0.42 & 0.27 & 0.29 & $0.68^{* *}$ & $0.59 *$ & 1.00 & --- & --- & --- & --- & -- \\
\hline SP & $-0.56^{*}$ & 0.15 & 0.09 & 0.03 & -0.12 & 0.24 & 0.24 & -0.32 & -0.16 & -0.34 & 1.00 & --- & --- & --- & --- \\
\hline PGA & 0.01 & 0.04 & 0.47 & 0.15 & 0.14 & 0.41 & 0.48 & 0.52 & $0.94^{* * *}$ & 0.47 & 0.18 & 1.00 & --- & --- & --- \\
\hline IPA & $0.66^{*}$ & 0.10 & 0.39 & 0.18 & 0.42 & 0.45 & $0.60^{*}$ & 0.49 & 0.15 & 0.27 & -0.18 & 0.10 & 1.00 & --- & --- \\
\hline
\end{tabular}

IDBIL = Internal dorsal bi-iliac, IMBIL = internal median bi-iliac, IVBIL = internal ventral bi-iliac, IBIS = internal bi-ischial, SP = sacropubic, PGA = pelvic girdle área, $\mathrm{AH}=$ animal height, $\mathrm{BL}=$ body length, $\mathrm{TW}=$ thoracic width, $\mathrm{TD}=$ thoracic depth, $\mathrm{EBIL}=$ external bi-iliac, EBIS $=$ external bi-ischial, EIIR $=$ external ilio-ischial right, EIIL = external ilio-ischial left, IPA = internal pelvic áre; ${ }^{*} \mathrm{p}<0.05,{ }^{* *} \mathrm{p}<0.01,{ }^{* * *} \mathrm{p}<0.001$.

Table 6. Evaluation of significance between pelvimetric measurements of 26 cows, 13 of these multiparous in the cyclic stage and 13 in the beginning of the puerperal stage of the Nelore breed, by the Tukey test

\begin{tabular}{|c|c|c|c|}
\hline Variable & Treatment & Mean $(\mathrm{N}=13)$ & Tukey $(\mathrm{P}<5 \%)$ \\
\hline \multirow[t]{2}{*}{ Thoracic width } & Cows in the early puerperal stage & 37.4231 & $\mathrm{~A}$ \\
\hline & Cows in the cycling stage & 34.8845 & B \\
\hline \multirow[t]{2}{*}{ Internal dorsal Bi-iliac } & Cows in the early puerperal stage & 15.5000 & A \\
\hline & Cows in the cycling stage & 14.5385 & $\mathrm{~B}$ \\
\hline \multirow[t]{2}{*}{ Internal pelvic area } & Cows in the early puerperal stage & 296.1394 & A \\
\hline & Cows in the cycling stage & 268.8317 & B \\
\hline
\end{tabular}

\begin{tabular}{ll}
\hline Sacropubic & $\begin{array}{l}\text { Cows in the early puerperal stage } \\
\text { Cows in the cycling stage } \\
\text { Cows in the early puerperal stage } \\
\text { Cows in the cycling stage }\end{array}$ \\
Thoracic area & Cows in the early puerperal stage \\
Cows in the cycling stage
\end{tabular}

the present work for animals in the cycling stage $(0.10)$ and early puerperal stages (0.14) (Table 4 and 5). Most negative correlations found between characteristic pairs in the present work were low, thus, the development of these characteristics assume opposite directions. Some correlations were classified as moderate, for example the correlation between thoracic width and internal bi-ischial breadth in animals in the cycling stage ( $\mathrm{r}=-0.59)$ (Table 4), which indicates that the development of these characteristics is inversely proportional.

The internal pelvic area encompasses better the pelvic girdle area than the internal dorsal bi-iliac breadth, which is not fully understood in the calculation of the pelvic girdle area and is fully included in the internal pelvic area. The correlation between internal pelvic area and pelvic girdle area was significant for animals in the cycling stage $(\mathrm{r}=0.77)$, and in the early puerperal stage $(r=0.10)$ (Table 4 and 5).

Significant correlation between thoracic perimeter and internal dorsal bi-iliac breadth was also found for both

$\begin{array}{cc}\text { Mean }(\mathrm{N}=13) & \text { Tukey }(\mathrm{P}<1 \%) \\ 19.0768 & \text { A } \\ 17.6538 & \text { B } \\ 66.4614 & \text { A } \\ 63.5000 & \text { B } \\ 1956.1290 & \text { A } \\ 1736.4440 & \text { B }\end{array}$

groups of animals (Table 4 and 5), indicating that this can be a parameter for selection of animals for characteristics related to pelvic area.

The comparison of means by the Tukey's test at significance level of $5 \%$ showed significant differences between external and internal dimensions of the animals in the cycling and early puerperal stages. Thoracic width, internal dorsal bi-iliac breadth, and internal pelvic area of animals in the early puerperal stage were higher than those found in animals in the cycling stage. The Tukey's test at significance level of $1 \%$ showed significantly different sacropubic diameter and thoracic perimeter between animals, with higher means in the puerperal stage when compared to animals in the cycling stage (Table 6).

\section{CONCLUSIONS}

The pelvic anatomy of Nellore cows varies according to their reproductive stage. 
Assessment of the pelvic area using the formula proposed for the internal pelvic area is important, since it can confirm statistical differences in the areas of pelvic components between animals in the cycling and early puerperal stages.

Conflict of interest statement.- The authors have no competing interests.

\section{REFERENCES}

Araújo A.A.O., Farias L.A., Biagiotti D. \& Ferreira G.J.B.C. 2014. Pelvimetria de suínos das linhagens Agroceres e DanBred. Revta Bras. Ciênc. Vet. 21(4):262-267.

Barreto P.B.M., Santos B.M.R., Wischral A., Cavalcanti Júnior M.J., Maia J.A.A., Soares P.C. \& Barbosa E.E.V. 2004. Pelvimetria e pelviologia em fêmeas bovinas da raça Girolanda em diferentes estágios reprodutivos. Ciênc. Vet. Tróp. 7(2):131-139.

Bellows R.A., Short R.E., Anderson D.C., Knapp B.W. \& Pahnish O.F. 1971 Cause and effect relationships associated with calving difficulty and calf birth weight. J. Anim. Sci. 33(2):407-415. <http://dx.doi.org/10.2527/ jas1971.332407x > <PMid:5106173>

Cunningham J.G. 1999. Tratado de Fisiologia Veterinária. 2a ed. Guanabara Koogan, Rio de Janeiro. 528p.

Dematawena C.M.B. \& Berger P.J. 1997. Effect of dystocia on yield, fertility, and cow losses and economic evaluation of dystocia scores for Holsteins. J. Dairy Sci. 80(4):754-761. <http://dx.doi.org/10.3168/jds.S00220302(97)75995-2> <PMid:9149970>

Derivaux J. \& Ectors F. 1984. Fisiopatologia de La Gestacion y Obstetricia Veterinária. Acribia, Zaragoza. 277p.

Deutscher G.H. 1978. Factors influencing dystocia and pelvic area in beef heifers. J. Anim. Sci. 47(Suppl.1):8.

Deutscher G.H. 1985. Using pelvic measurements to reduce dystocia in heifers. Modern Vet. Pract. 16:751-755.

Getty R. 1986. Sisson and Grossman Anatomia dos Animais Domésticos. Vol.1. 5a ed. Guanabara Koogan, Rio de Janeiro. 710p.

Hafez E.S.E. \& Hafez B. 2000. Reproduction in Farm Animals. 7th ed. Lippincott Williams and Wilkins, Philadelphia. 509p. <http://dx.doi. org/10.1002/9781119265306>.

Johnson S.K., Deutscher G.H. \& Parkhurst A. 1988. Relationship of pelvic structure, body measurement, pelvic area and calving difficulty. J. Anim. Sci. 66(5):1081-1088. <http://dx.doi.org/10.2527/jas1988.6651081x> <PMid:3397334>

Knobil E. \& Neill J.D. 1994. The Physiology of Reproduction. 2nd ed. Raven Press, New York. 1372p.

Ko J.C.H. \& Ruble M.V. 1990. Using maternal pelvis size and fetal hoof circumference to predict calving difficulty in beef cattle. Vet. Med. 85:1030-1036.
Kolkman I., Hoflack G., Aerts S., Murray R.D., Opsomer G. \& Lips D. 2009. Evaluation of the Rice pelvimeter for measuring pelvic area in double muscled Belgian Blue cows. Livest. Sci. 121(2/3):259-266. <http://dx.doi. org/10.1016/j.livsci.2008.06.022>

Koury Filho W., Albuquerque L.G., Forni S., Silva J.A.V., Yokoo M.J. \& Alencar M.M. 2010. Estimativas de parâmetros genéticos para os escores visuais e suas associações com peso corporal em bovinos de corte. Revta Bras. Zool. 39(5):1015-1022. <http://dx.doi.org/10.1590/S151635982010000500011>

Meijering A. 1984. Dystocia and stillbirth in cattle: a review of causes, relations and implications. Livest. Prod. Sci. 11(2):143-177.<http://dx.doi. org/10.1016/0301-6226(84)90057-5>

Nix J.M., Spitzer J.C., Grimes L.W., Burns G.L. \& Plyler B.B. 1998. A retrospective analysis of factors contributing to calf mortality and dystocia in beef cattle. Theriogenology 49(8):1515-1523. <http://dx.doi.org/10.1016/S0093691X(98)00097-1><PMid:10732015>

Okuda H.T., Pedutti N.J., Bombonato P.P., Vuono L., Valério Filho W.V. \& Maçal V. 1994. Influência do parto na pelvimetria de vacas da raça guzerá. Revta Fac. Zootec. Vet. Agron. Uruguaiana 1(1):39-48.

Oliveira A.C., Bombonato P.P., Baruselli P.S., Oliveira J.F.S. \& Souza A.0. 2001. Pelvimetria e pelvilogia em búfalas mestiças (Bubalus bubalis). Brazilian J. Vet. Res. Anim. Sci. 38(3):114-121. <http://dx.doi.org/10.1590/S141395962001000300004>

Oliveira P.C., Bombonato P.P. \& Balieiro J.C.C. 2003. Pelvimetria em vacas Nellore. Brazilian J. Vet. Res. Anim. Sci. 40(4):297-304. <http://dx.doi. org/10.1590/S1413-95962003000400009>

Paschal J.C., Sanders J.O. \& Kerr J.L. 1991. Calving and weaning characteristics of Angus-, Gray Brahman-, Gir-, InduBrazil-, Nellore-, and Red Brahman-sired F1 calves. J. Anim. Sci. 69(6):2395-2402. <http://dx.doi. org/10.2527/1991.6962395x><PMid:1885357>

Rezende M.P.G., Ferraz P.C., Carneiro P.L. S. \& Malhado C.H.M. 2017.Phenotypic diversity in buffalo cows of the Jafarabadi, Murrah, and Mediterranean breeds. Pesq. Agropec. Bras., Brasília, 52(8):663-669.

Rice L.E. 1994. Dystocia, related risk factors. Vet. Clin. N. Am., Food Anim. Pract. 10(1):53-68.

Roberts S.J. 1986. Veterinary Obstetrics and Genital Diseases, Theriogenology. 3rd ed. David and Charles Inc., North Pomfret, Woodstock. 981p.

Schafhauser Jr J., Mancio A.B., Fontes C.A.C., Torres C.A.A., Paulino M.F. \& Cecon P.R. 2004. Desempenho reprodutivo de novilhas com diferente grau de musculosidade. Revta Zootec. Vet. Agron. Uruguaiana 10:2-19.

Tsousis G., Heun C., Becker M. \& Bollwein H. 2010. Application of computed tomography for the evaluation of obstetrically relevant pelvic parameters in German Holstein-Friesian cows. Theriogenology 73(3):309-315. <http://dx.doi.org/10.1016/j.theriogenology.2009.09.014> $<$ PMid:19959219> 